\title{
Natrialba hulunbeirensis sp. nov. and Natrialba chahannaoensis sp. nov., novel haloalkaliphilic archaea from soda lakes in Inner Mongolia Autonomous Region, China
}

\author{
1 Institute of Microbiology, \\ Chinese Academy of \\ Sciences, Zhongguancun \\ district, Beijing 100080, \\ China \\ 2 Department of \\ Microbiology and \\ Parasitology, Faculty of \\ Pharmacy, University of \\ Sevilla, 41012 Sevilla, Spain \\ 3 Department of \\ Microbiology and \\ Immunology, University of \\ Leicester, Leicester \\ LE1 9HN, UK
}

\author{
Yi Xu, ${ }^{1}$ Zhenxiong Wang, ${ }^{1}$ Yanfen Xue, ${ }^{1}$ Peijin Zhou, ${ }^{1}$ Yanhe Ma, ${ }^{1}$ \\ Antonio Ventosa ${ }^{2}$ and William D. Grant ${ }^{3}$
}

\begin{abstract}
Author for correspondence: Yanhe Ma. Tel: +86 10 62553628. Fax: +86 1062560912. e-mail:mayh@sun.im.ac.cn
\end{abstract}

\begin{abstract}
Two haloalkaliphilic archaeal strains, $\mathrm{X21}^{\top}$ and $\mathrm{C}^{112}{ }^{\top}$, were isolated from soda lakes in Inner Mongolia Autonomous Region, China. Their morphology, physiology, biochemical features, polar lipid composition and 16S rRNA genes were characterized in order to elucidate their taxonomy. According to these data, strains $\mathrm{X21}^{\top}$ and $\mathrm{C}^{112^{\top}}$ belong to the genus Natrialba, although there are clear differences with respect to their physiology and polar lipid composition between the two strains and the type species, Natrialba asiatica. On the basis of low DNA-DNA hybridizations, these two strains should be considered as new species of genus Natrialba. The names Natrialba hulunbeirensis sp. nov. (type strain X21 ${ }^{\top}=$ AS $1.1986^{\top}=J^{\top}$ JM $^{10989^{\top}}$ ) and Natrialba chahannaoensis sp. nov. (type strain $\mathrm{C}^{112^{\top}}=$ AS $1.1977^{\top}=\mathrm{JCM}^{10990^{\top}}$ ) are proposed.
\end{abstract}

Keywords: Natrialba hulunbeirensis, Natrialba chahannaoensis, archaea, haloalkaliphiles

\section{INTRODUCTION}

The family Halobacteriaceae was proposed by Gibbons (1974) to accommodate the rods and cocci that required high concentrations (more than $12 \%$, $\mathrm{w} / \mathrm{v}$ ) of sodium chloride for growth, and included two genera, Halobacterium and Halococcus. The isolation of haloalkaliphilic and pleomorphic halobacteria necessitated the extension of this scheme to include six genera: Halobacterium, Halococcus, Haloarcula, Haloferax, Natronobacterium and Natronococcus (Grant \& Larsen, 1989; Torreblanca et al., 1986). Currently, members of the aerobic, extremely halophilic archaea are classified in 15 genera: Halobacterium, Halococcus, Haloarcula, Haloferax, Halorubrum, Halobaculum, Natrialba, Natronomonas, Natronobacterium, Natronococcus, Halogeometricum, Natrinema, Haloterrigena, Natronorubrum and Halorhabdus (McGenity \& Grant, 1995; Oren et al., 1995; Kamekura \& Dyall-

\footnotetext{
Abbreviations: PG, phosphatidylglycerol; PGP-Me, phosphatidylglycerophosphate methyl ester; $\mathrm{S}_{2}-\mathrm{DGD}-1,2,6-\mathrm{HSO}_{3}-\operatorname{Man} p-\alpha(1 \rightarrow 2)-\mathrm{Gl} c p-\alpha(1 \rightarrow 1)$ sn-glyceroldiether.

The GenBank accession numbers for the 165 rDNA sequences of strains $X 21^{\top}$ and $\mathrm{C}_{112^{\top}}$ are respectively AF262026 and AJ004806.
}

Smith, 1995; Kamekura et al., 1997; MontalvoRodríguez et al., 1998; McGenity et al., 1998; Ventosa et al., 1999; Xu et al., 1999; Wainø et al., 2000). Most halobacteria are neutrophilic, but some of these genera include species that are haloalkaliphilic, requiring not only high $\mathrm{NaCl}$ concentrations but also high $\mathrm{pH}$ and low $\mathrm{Mg}^{2+}$ concentrations for growth.

The phenotypic characteristics of haloalkaliphilic archaea that permit their differentiation are comparatively very limited, so it is relatively difficult to classify them on the basis of their phenotypic features alone. In addition, their phospholipid composition is highly conserved and glycolipids are absent from the majority of strains. Thus, chemotaxonomy on the basis of lipid composition is difficult. Therefore, in combination with other phenotypic features such as morphology, physiology and biochemistry, the phylogenetic inference of $16 \mathrm{~S}$ rRNA sequences and DNADNA hybridization play important roles in the classification of haloalkaliphilic archaea. In 1997, the ICSB Subcommittee on the Taxonomy of Halobacteria proposed minimum standards for the classification of halobacterial archaea and suggested that the classification of halobacteria should be polyphasic and consistent with the phylogenetic analysis of 16S rRNA 
gene sequences (Oren et al., 1997). Recently, great progress has been made in the classification of haloalkaliphilic archaea: Kamekura et al. (1997) classified some species previously included in the genus Natronobacterium into three different genera: Natronomonas, Natrialba and Halorubrum. Additionally, $\mathrm{Xu}$ et al. (1999) proposed a new genus, Natronorubrum, with two new haloalkaliphilic species, Natronorubrum bangense and Natronorubrum tibetense.

In this study, we describe two novel soda lake isolates, $\mathrm{X} 21^{\mathrm{T}}$ and $\mathrm{C} 112^{\mathrm{T}}$. We have determined the complete $16 \mathrm{~S}$ rDNA sequences of these isolates, as well as their polar lipid compositions. In addition, we have performed DNA-DNA hybridization experiments with other members of the genus Natrialba in order to determine the taxonomic positions of strains $\mathrm{X} 21^{\mathrm{T}}$ and $\mathrm{C} 112^{\mathrm{T}}$.

\section{METHODS}

Bacterial strains and culture conditions. Strain $\mathrm{X} 21^{\mathrm{T}}$ was isolated by enrichment from a sediment sample ( $\mathrm{pH} \mathrm{10)}$ collected from Chahannao soda lake in the Inner Mongolia Autonomous Region of China, whereas strain $\mathrm{C} 112^{\mathrm{T}}$ was isolated from a sediment sample ( $\mathrm{pH} 9 \cdot 5)$ of an unnamed soda lake in the Hulunbeir prefecture of the Inner Mongolia Autonomous Region, China. The medium and methods for enrichment and isolation were described previously (Tindall et al., 1980). In addition, the following strains of the genus Natrialba were used in this study: Natrialba magadii NCIMB $2190^{\mathrm{T}}$ and Natrialba asiatica strains JCM $9576^{\mathrm{T}}$ and JCM 9577. These strains were cultivated aerobically at $37^{\circ} \mathrm{C}$ as described previously (Tindall, 1992). The growth medium for the following studies contained $\left(1^{-1}\right): 7 \cdot 5 \mathrm{~g}$ Casamino acids (Difco), $10 \mathrm{~g}$ yeast extract (Difco), $3.0 \mathrm{~g}$ trisodium citrate, $0 \cdot 3 \mathrm{~g} \mathrm{MgSO}_{4} \cdot 7 \mathrm{H}_{2} \mathrm{O}, 2 \cdot 0 \mathrm{~g} \mathrm{KCl}$, traces of $\mathrm{Fe}^{2+}$ and $\mathrm{Mn}^{2+}, 200 \mathrm{~g} \mathrm{NaCl}$ and $8.0 \mathrm{~g} \mathrm{Na}_{2} \mathrm{CO}_{3}$.

Phenotypic characterization. Phenotypic tests on strains $\mathrm{X} 21^{\mathrm{T}}$ and $\mathrm{C} 112^{\mathrm{T}}$ were carried out in accordance with the recommended standard methods for halobacteria (Oren et al., 1997). Cell motility and shape were examined by phasecontrast microscopy without fixation and by Gram staining with acetic acid fixation. The optimal conditions of growth, reduction of nitrate and utilization of different carbon sources were determined as described previously (Grant \& Tindall, 1980; Mwatha \& Grant, 1993). Tests for catalase and oxidase activities and hydrolysis of starch, gelatin, casein and Tween 80 were performed as described previously (Gonzalez et al., 1978). Antibiotic susceptibility and $\mathrm{H}_{2} \mathrm{~S}$ production was tested as described previously (Colwell et al., 1979). Growth was monitored by turbidity at $660 \mathrm{~nm}$.

Lipid composition. Total lipids were extracted and analysed on silica-gel plates (Kieselgel $60 \mathrm{~F}_{254}$; Merck) by one- and two-dimensional TLC (Ross et al., 1981; Ross, 1982). The core lipids were analysed by TLC, as described by Ross et al. (1981).

DNA base composition and DNA-DNA hybridization. Genomic DNA was prepared and purified as described previously (Zhou et al., 1994). The $\mathrm{G}+\mathrm{C}$ content of the DNA was determined by the thermal denaturation method (Marmur \& Doty, 1962). DNA-DNA hybridization was carried out as described by Tindall et al. (1984) with a minor modification: DNA fragments were labelled with $\left[\alpha-{ }^{32} \mathrm{P}\right] \mathrm{dCTP}$ using a nick-translation kit (Boehringer Mannheim).

16S rRNA gene sequence and phylogenetic analysis. The methods used for DNA preparation, PCR amplification of 16S rRNA genes and gene sequencing were described previously (Zhou et al., 1994).

Multiple sequence alignments were performed using CLUSTAL W version 1.8 (Thompson et al., 1994). Phylogenetic analysis of multiple sequence alignments was performed with TREECON W version 1.3b (Van de Peer \& De Wachter, 1994). Phylogenetic tree construction was carried out by the neighbour-joining method with Kimura's two-parameter calculation model in TREECON W version $1.3 \mathrm{~b}$.

\section{RESULTS}

\section{Morphology}

The two strains $\mathrm{X} 21^{\mathrm{T}}$ and $\mathrm{C} 112^{\mathrm{T}}$ were Gram-negative, rod-shaped and non-motile. Cells were $0.4-0.6 \times$ $1-2.5 \mu \mathrm{m}$ and lysed in distilled water. On agar plates, both strains formed red, circular and smooth colonies, $0.5 \mathrm{~mm}$ in diameter for strain $\mathrm{X} 21^{\mathrm{T}}$ and $2.0 \mathrm{~mm}$ in diameter for strain $\mathrm{C} 112^{\mathrm{T}}$ after 1 week at $37^{\circ} \mathrm{C}$.

\section{Physiological characterization}

Growth of both strains occurred in the $\mathrm{pH}$ range $8 \cdot 5-10 \cdot 5$, with optimum growth at $\mathrm{pH} 9 \cdot 0$. Strain $\mathrm{X} 21^{\mathrm{T}}$ grew in media containing between 12 and $30 \%(\mathrm{w} / \mathrm{v})$ $\mathrm{NaCl}$, with an optimum at $20 \%(\mathrm{w} / \mathrm{v}) \mathrm{NaCl}$. Strain $\mathrm{C} 112^{\mathrm{T}}$ grew in media containing between 10 and $30 \%$ (w/v) $\mathrm{NaCl}$, with an optimum at $15 \%$ (w/v) $\mathrm{NaCl}$. Growth of both strains occurred in the temperature range $20-55^{\circ} \mathrm{C}$, with respective optima at 50 and $45^{\circ} \mathrm{C}$ for strains $\mathrm{X} 21^{\mathrm{T}}$ and $\mathrm{C} 112^{\mathrm{T}}$.

Both strains were catalase- and oxidase-positive and strictly aerobic. Both strains reduced nitrate to nitrite anaerobically and produced $\mathrm{H}_{2} \mathrm{~S}$ from cysteine but not from $\mathrm{Na}_{2} \mathrm{~S}_{2} \mathrm{O}_{3}$. They were sensitive to some antibiotics (such as erythromycin, rifampicin and bacitracin) but insensitive to tetracycline hydrochloride. Both strains hydrolysed gelatin and did not hydrolyse Tween 80 . Strain $\mathrm{X} 21^{\mathrm{T}}$ hydrolysed Tween 40 but did not hydrolyse starch or casein. Strain $\mathrm{C} 112^{\mathrm{T}}$ hydrolysed starch and casein but did not hydrolyse Tween 40 . Both strains utilized some sugars (fructose and maltose) and amino acids (asparagine, arginine and proline) as sole carbon sources for growth. They were unable to use sucrose, lactose, mannitol, serine, threonine or isoleucine. In addition, strain $\mathrm{C} 112^{\mathrm{T}}$ utilized glucose, acetate and lysine as sole carbon sources for growth, but strain $\mathrm{X} 21^{\mathrm{T}}$ did not. Acid production by both strains was observed from fructose and maltose, but not from glucose.

\section{Polar lipids}

Two-dimensional TLC revealed that the major polar lipids present in both strains were diphytanyl moieties $\left(\mathrm{C}_{20}-\mathrm{C}_{20}\right)$ and phytanyl-sesterterpenyl moieties 


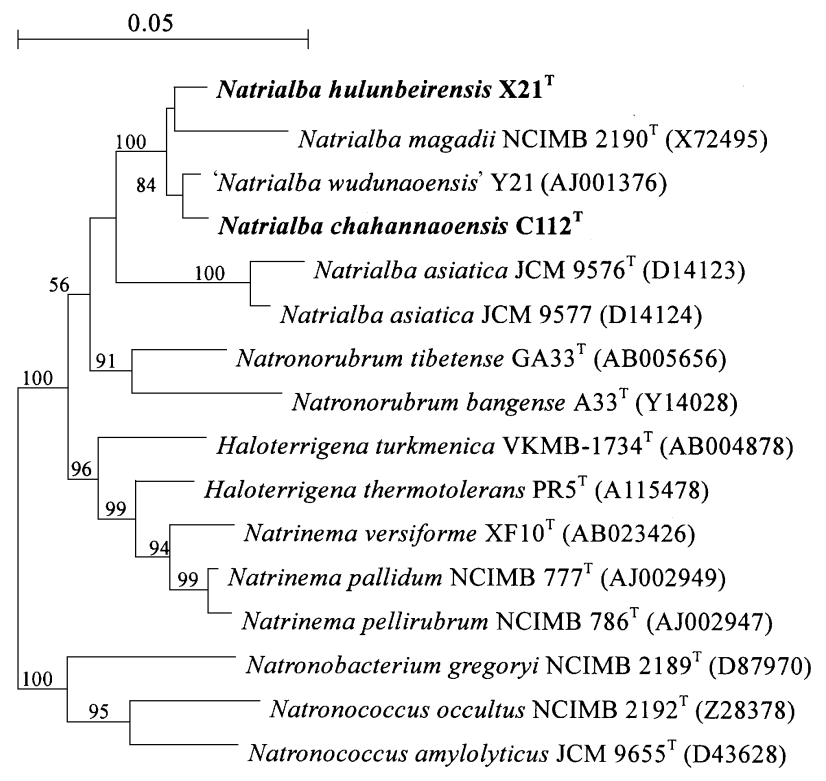

Fig. 1. Phylogenetic tree of Natrialba and related genera from their 165 rDNA sequences. The tree was constructed by the neighbour-joining method and Kimura's two-parameter calculation model. Numbers represent confidence levels from 100 replicate bootstrap sampling. Bar, 0.05 expected changes per site.

$\left(\mathrm{C}_{20}-\mathrm{C}_{25}\right)$ of phosphatidylglycerol (PG) and phosphatidylglycerophosphate methyl ester (PGP-Me). Glycolipids were not present. In addition, a minor amount of an unidentified polar lipid was present in strain X21 ${ }^{\mathrm{T}}$.

\section{S rRNA gene sequence analysis}

The almost complete sequences of the 16S rDNA from strains $\mathrm{X} 21^{\mathrm{T}}$ and $\mathrm{C} 112^{\mathrm{T}}$, with respective lengths of 1472 and $1474 \mathrm{bp}$, were determined and compared to the sequences of members of the genus Natrialba and other closely related halobacteria. Positions with any gaps and alignment uncertainty were omitted from the analysis. A total of 1376 unambiguous nucleotides were used for computing evolutionary distance. The phylogenetic tree (Fig. 1) indicated that the two strains were closely related to the species of the genus Natrialba and constituted a subgroup with the two described haloalkaliphilic species (Natrialba magadii NCIMB $2190^{\mathrm{T}}$ and 'Natrialba wudunaoensis' Y21). The sequence similarities of strain $\mathrm{X} 21^{\mathrm{T}}$ were $98.6 \%$ to strain $\mathrm{C} 112^{\mathrm{T}}, 97 \cdot 3 \%$ to Natrialba magadii NCIMB $2190^{\mathrm{T}}, 98.9 \%$ to 'Natrialba wudunaoensis' Y21, $94.7 \%$ to Natrialba asiatica JCM $9576^{\mathrm{T}}$ and $95.5 \%$ to Natrialba asiatica JCM 9577. The sequence similarities of strain $\mathrm{C}_{112^{\mathrm{T}}}$ were $96.8 \%$ to Natrialba magadii NCIMB $2190^{\mathrm{T}}, 99 \cdot 2 \%$ to 'Natrialba wudunaoensis' Y $21,95.4 \%$ to Natrialba asiatica JCM $9576^{\mathrm{T}}$ and $96 \%$ to Natrialba asiatica JCM 9577. Strains X21 ${ }^{\mathrm{T}}$ and $\mathrm{C} 112^{\mathrm{T}}$ respectively had 95.4 and $95.5 \%$ sequence similarity to Natronorubrum tibetense GA $33^{\mathrm{T}}, 95.5$ and 95.4\% sequence similarity to Haloterrigena thermo-
Table 1. DNA-DNA hybridization between strains $X 21^{\top}$ and $\mathrm{C}_{112^{\top}}$ and other type strains of species of the genus Natrialba

\begin{tabular}{|c|c|c|}
\hline Strain & $\mathrm{X} 21^{\mathrm{T}}$ & $\mathrm{C}_{112}{ }^{\mathrm{T}}$ \\
\hline Strain $X 21^{\mathrm{T}}$ & 100 & - \\
\hline Strain $\mathrm{C} 112^{\mathrm{T}}$ & 29 & 100 \\
\hline Natrialba magadii NCIMB $2190^{\mathrm{T}}$ & 36 & 13 \\
\hline Natrialba asiatica JCM 9576 & 18 & 3 \\
\hline 'Natrialba wudunaoensis' Y21 & 26 & 37 \\
\hline
\end{tabular}

tolerans $\mathrm{PR} 5^{\mathrm{T}}$ and 95.2 and $95.0 \%$ sequence similarity to Natrinema pallidum NCIMB $777^{\mathrm{T}}$. Strains X $21^{\mathrm{T}}$ and $\mathrm{C} 112^{\mathrm{T}}$ had less than $92 \%$ sequence similarity to members of the other genera of aerobic extremely halophilic archaea. The phylogenetic placement of the two strains (Fig. 1) indicated that strains $\mathrm{X} 21^{\mathrm{T}}$ and $\mathrm{C} 112^{\mathrm{T}}$ were members of the genus Natrialba.

\section{DNA-DNA hybridization and $\mathbf{G}+\mathrm{C}$ content of the DNA}

The DNA-DNA relatedness of the two strains $\left(\mathrm{X} 21^{\mathrm{T}}\right.$ and $\mathrm{C} 112^{\mathrm{T}}$ ) to other described species of the genus Natrialba is shown in Table 1. DNA-DNA hybridization indicated that both strains $\left(\mathrm{X} 21^{\mathrm{T}}\right.$ and $\mathrm{C} 112^{\mathrm{T}}$ ) had low DNA relatedness to the other described species of Natrialba (3-37\%) and, since the DNA hybridization was lower than $70 \%$ in all cases, strains $\mathrm{X} 21^{\mathrm{T}}$ and $\mathrm{C} 112^{\mathrm{T}}$ thus represent two distinct genospecies.

The $\mathrm{G}+\mathrm{C}$ contents of the genomic DNAs from strains $\mathrm{X} 21^{\mathrm{T}}$ and $\mathrm{C} 112^{\mathrm{T}}$ were respectively 64.3 and $63.7 \mathrm{~mol} \%$, as determined by the thermal denaturation method.

\section{DISCUSSION}

Some decades ago, halobacterial taxonomy was based mainly on physiological and morphological features (Gibbons, 1974). In the 1980s, polar lipid composition and 16S rRNA-DNA hybridization proved particularly useful in the classification of halobacteria (Ross \& Grant, 1985; Torreblanca et al., 1986), defining two additional genera (Haloarcula, Haloferax), but also indicating the need for further reclassification of some halobacterial species of uncertain taxonomic standing (Grant \& Larsen, 1989; Ross \& Grant, 1985). In recent years, more and more complete $16 \mathrm{~S}$ rRNA gene sequences have become available for the halobacteria. Phylogenetic analysis of 16S rRNA gene sequences has now shown considerable taxonomic diversity within the family Halobacteriaceae (Kamekura \& DyallSmith, 1995; McGenity \& Grant, 1995; Duckworth et al., 1996) and, to date, 15 genera have been described, including a number of genera where representative strains are all haloalkaliphilic and others that include some haloalkaliphilic types. 
Table 2. Major features of strains $\mathrm{X} 21^{\top}$ and $\mathrm{C} 112^{\top}$ and species of the genus Natrialba

Taxa are indicated as: 1 , strain X21 ${ }^{\mathrm{T}} ; 2$, strain $\mathrm{C} 112^{\mathrm{T}} ; 3$, Natrialba magadii NCIMB $2190^{\mathrm{T}} ; 4$, Natrialba asiatica JCM 9576 ${ }^{\mathrm{T}} ; 5$, Natrialba asiatica JCM 9577; 6, 'Natrialba wudunaoensis' Y21. Cells of all strains are rods and stain Gram-negative. All strains are positive for catalase, oxidase and hydrolysis of gelatin. NR, Not reported.

\begin{tabular}{|c|c|c|c|c|c|c|}
\hline Characteristic & 1 & 2 & 3 & 4 & 5 & 6 \\
\hline Motility & - & - & + & + & + & - \\
\hline Colony pigmentation & Red & Red & Orange-red & White & Pale-yellow & Red \\
\hline \multicolumn{7}{|c|}{$\mathrm{NaCl}$ concentration for growth $(\%)$ : } \\
\hline Optimum & 20 & 15 & 20 & 24 & 20 & 18 \\
\hline Range & $12-30$ & $10-30$ & $12-30$ & $12-30$ & $12-30$ & $12-25$ \\
\hline Optimum temperature $\left({ }^{\circ} \mathrm{C}\right)$ & 50 & 45 & $37-40$ & $30-40$ & $35-40$ & 40 \\
\hline Optimum pH & $9 \cdot 0$ & $9 \cdot 0$ & $9 \cdot 5$ & $6 \cdot 6-7 \cdot 0$ & $7 \cdot 5-7 \cdot 8$ & $9 \cdot 0$ \\
\hline $\mathrm{H}_{2} \mathrm{~S}$ production from cysteine & + & + & + & - & + & + \\
\hline Nitrate reduction & + & + & - & + & + & + \\
\hline \multicolumn{7}{|l|}{ Hydrolysis of: } \\
\hline Starch & - & + & - & - & + & - \\
\hline Casein & - & + & + & + & + & + \\
\hline \multicolumn{7}{|l|}{ Utilization of: } \\
\hline Glucose & - & + & - & - & + & - \\
\hline Fructose & + & + & - & - & + & + \\
\hline Maltose & + & + & - & - & + & + \\
\hline Acetate & - & + & + & $\mathrm{NR}$ & $\mathrm{NR}$ & + \\
\hline DNA G $+\mathrm{C}$ content $(\mathrm{mol} \%)$ & $64 \cdot 3$ & $63 \cdot 7$ & $63 \cdot 0$ & $60 \cdot 3-63 \cdot 1$ & $60 \cdot 3-63 \cdot 1$ & $65 \cdot 4$ \\
\hline Polar lipid composition & PG, PGP-Me & PG, PGP-Me & PG, PGP-Me & PG, PGP-Me, $\mathrm{S}_{2}$-DGD-1 & PG, PGP-Me, $\mathrm{S}_{2}$-DGD-1 & PG, PGP-Me \\
\hline
\end{tabular}

A number of haloalkaliphiles have been isolated from soda lakes in the Inner Mongolia Autonomous Region of China, including strain Y21, which has been shown to be a species of Natrialba (Wang et al., 2000), the strains described here, $\mathrm{X} 21^{\mathrm{T}}$ and $\mathrm{C} 112^{\mathrm{T}}$, and some incompletely characterized strains, such as X213, C212 and Y212 (Wang \& Tang, 1989). We now report the full characterization of the two strains $\mathrm{X} 21^{\mathrm{T}}$ and $\mathrm{C} 112^{\mathrm{T}}$, which show features typical of the archaeal genus Natrialba (Table 2). Our results show that both strains are typical members of the haloalkaliphilic archaea, growing optimally in the presence of $20 \%$ $\mathrm{NaCl}(\mathrm{w} / \mathrm{v})$ at $\mathrm{pH} 9 \cdot 0$ and containing $\mathrm{C}_{20}-\mathrm{C}_{20} / \mathrm{C}_{20}-\mathrm{C}_{25}$ diether core lipids of PG and PGP-Me. The genus Natrialba contains non-alkaliphilic and alkaliphilic species and they have different polar lipid compositions. As shown in Table 2, there are two subgroups in the genus Natrialba; members of one subgroup (Natrialba asiatica JCM $9576^{\mathrm{T}}$ and JCM 9577) contain a glycolipid (2,6- $\mathrm{HSO}_{3}-\mathrm{Man} p-\alpha(1 \rightarrow 2)$ Glc $p-\alpha(1 \rightarrow 1)$-sn-glyceroldiether; $\mathrm{S}_{2}$-DGD-1) in addition to phospholipids (PG and PGP-Me), and members of the other subgroup (Natrialba magadii NCIMB $2190^{\mathrm{T}}$ and our two isolates) contain only PG and PGP-Me. This feature would imply that the genus Natrialba constitutes a heterogeneous group and it is not in accordance with the principles of polyphasic taxonomy (Grant \& Larsen, 1989; Oren et al., 1997). Future studies should clarify the classification of the entire group.

The 16S rDNA sequences of the two strains $\left(\mathrm{X} 21^{\mathrm{T}}\right.$ and $\mathrm{C} 112^{\mathrm{T}}$ ) exhibited high levels of similarity to that of their closest counterpart, 'Natrialba wudunaoensis' Y21 (98.9 and $99.2 \%$, respectively), and also to that of Natrialba magadii NCIMB $2190^{\mathrm{T}}(97 \cdot 3$ and $96 \cdot 8 \%$ ). Although the two strains possessed a close phylogenetic relationship to the members of the genus
Natrialba, the DNA-DNA relatedness was lower than $70 \%$ with previously described members of this genus, indicating that the two strains are genetically distinct from species described previously and should be classified as new species of the genus Natrialba. With regard to the taxonomic position of the two new strains and Natrialba magadii NCIMB $2190^{\mathrm{T}}$, although they have a relatively close relationship to Natrialba asiatica JCM $9576^{\mathrm{T}}$ (Fig. 1), it could be argued that these alkaliphilic halobacteria could be placed in a different genus because they have different polar lipid compositions and phenotypic characters from the type species of the genus, Natrialba asiatica.

On the basis of the data described above, the two haloalkaliphilic archaea, strains $\mathrm{X} 21^{\mathrm{T}}$ and $\mathrm{C} 112^{\mathrm{T}}$, represent new members of the genus Natrialba, for which we propose the names Natrialba hulunbeirensis sp. nov. (strain $\mathrm{X} 21^{\mathrm{T}}$ ) and Natrialba chahannaoensis sp. nov. (strain $\mathrm{C} 112^{\mathrm{T}}$ ).

\section{Description of Natrialba hulunbeirensis sp. nov.}

Natrialba hulunbeirensis (hu.lun.bei.ren'sis. N.L. adj. hulunbeirensis of Hulunbeir, relating to the isolation of the organism from a soda lake of Hulunbeir prefecture, China).

Cells are rod-shaped, 0.4-0.6 $\times 1-2.5 \mu \mathrm{m}$, non-motile, uniformly stained Gram-negative, strictly aerobic and lysed in distilled water. Colonies are red, circular, smooth and $0.5 \mathrm{~mm}$ in diameter after 1 week of incubation. Growth occurs in media containing between 12 and $30 \% \mathrm{NaCl}$; optimum at $20 \% \mathrm{NaCl}$. The $\mathrm{pH}$ range for growth is $8 \cdot 5-10 \cdot 5$, with an optimum at $\mathrm{pH} 9 \cdot 0$. The temperature range for growth is between 20 and $55^{\circ} \mathrm{C}$, with an optimum at $50{ }^{\circ} \mathrm{C}$. Oxidase and catalase are positive. The following substrates are 
utilized for growth: asparagine, arginine, proline, fructose and maltose. Serine, threonine, isoleucine, lysine, acetate, glucose, sucrose, lactose and mannitol are not utilized for growth. Starch, casein and Tween 80 are not hydrolysed. Gelatin is liquefied. Tween 40 is hydrolysed. $\mathrm{H}_{2} \mathrm{~S}$ is produced from cysteine but not from thiosulfate. Nitrate is reduced. Sensitive to erythromycin, bacitracin and rifampicin but not to tetracycline. The polar lipids are $\mathrm{C}_{20}-\mathrm{C}_{20}$ and $\mathrm{C}_{20}-\mathrm{C}_{25}$ derivatives of PG, PGP-Me and an uncharacterized minor polar lipid. The $\mathrm{G}+\mathrm{C}$ content of the DNA is $64.3 \mathrm{~mol} \%\left(T_{\mathrm{m}}\right)$. Isolated from a soda lake in China.

The type strain is strain $\mathrm{X} 21^{\mathrm{T}}$, deposited in the Academia Sinica, China General Microbiological Culture Collection as AS $1.1986^{\mathrm{T}}$ and as JCM $10989^{\mathrm{T}}$.

\section{Description of Natrialba chahannaoensis sp. nov.}

Natrialba chahannaoensis (cha.han.nao.en'sis. N.L. adj. chahannaoensis of Chahannao, referring to its isolation from Chahannao soda lake, China).

Cells are rod-shaped, 0.4-0.6 $\times 1-2.5 \mu \mathrm{m}$, non-motile, uniformly stained Gram-negative, strictly aerobic and lysed in distilled water. Colonies are red, circular, smooth and $2.0 \mathrm{~mm}$ in diameter after 1 week of incubation. Growth occurs in media containing between 10 and $30 \% \mathrm{NaCl}$; optimum at $15 \% \mathrm{NaCl}$. The $\mathrm{pH}$ range for growth is $8.5-10.5$, with an optimum at $\mathrm{pH} 9 \cdot 0$. The temperature range for growth is between 20 and $55^{\circ} \mathrm{C}$, with an optimum at $45^{\circ} \mathrm{C}$. Oxidase and catalase are positive. The following substrates are utilized for growth: asparagine, arginine, proline, lysine, glucose, fructose, maltose and acetate. Serine, threonine, isoleucine, sucrose, lactose and mannitol are not utilized for growth. Starch, casein and gelatin are hydrolysed. Tweens 40 and 80 are not hydrolysed. $\mathrm{H}_{2} \mathrm{~S}$ is produced from cysteine but not from thiosulfate. Nitrate is reduced. Sensitive to erythromycin, bacitracin and rifampicin but not to tetracycline. The polar lipids are $\mathrm{C}_{20}-\mathrm{C}_{20}$ and $\mathrm{C}_{20}-\mathrm{C}_{25}$ derivatives of $\mathrm{PG}$ and PGP-Me. The $\mathrm{G}+\mathrm{C}$ content of the DNA is $63.7 \mathrm{~mol} \%\left(T_{\mathrm{m}}\right)$. Isolated from a soda lake in China. The type strain is strain $\mathrm{C} 112^{\mathrm{T}}\left(=\mathrm{AS} 1.1977^{\mathrm{T}}=\mathrm{JCM}\right.$ $10990^{\mathrm{T}}$ ).

\section{ACKNOWLEDGEMENTS}

We thank M. Kamekura for his kind advice. This work was partially supported by a grant from the National Natural Science Foundation of China and a grant from the Chinese Academy of Sciences.

\section{REFERENCES}

Colwell, R. R., Litchfield, C. D., Vreeland, R. H., Kiefer, L. A. \& Gibbons, N. E. (1979). Taxonomic studies of red halophilic bacteria. Int J Syst Bacteriol 29, 379-399.

Duckworth, A. W., Grant, W. D., Jones, B. E. \& van Steenbergen, R. (1996). Phylogenetic diversity of soda lake alkaliphiles. FEMS Microbiol Ecol 19, 181-191.

Gibbons, N. E. (1974). Family V. Halobacteriaceae fam. nov. In Bergey's Manual of Determinative Bacteriology, 8th edn, pp.
269-273. Edited by R. E. Buchanan \& N. E. Gibbons. Baltimore: Williams \& Wilkins.

Gonzalez, C., Gutierrez, C. \& Ramirez, C. (1978). Halobacterium vallismortis sp. nov. An amylolytic and carbohydratemetabolizing, extremely halophilic bacterium. Can J Microbiol 24, 710-715.

Grant, W. D. \& Larsen, H. (1989). Group III. Extremely halophilic archaebacteria. Order Halobacteriales ord. nov. In Bergey's Manual of Systematic Bacteriology, vol. 3, pp. 2216-2233. Edited by J. T. Staley, M. P. Bryant, N. Pfennig \& J. G. Holt. Baltimore: Williams \& Wilkins.

Grant, W. D. \& Tindall, B. J. (1980). The isolation of alkalophilic bacteria. In Microbial Growth and Survival in Extreme Environments, pp. 27-33. Edited by G. W. Gould \& J. C. L. Corry. New York: Academic Press.

Kamekura, M. \& Dyall-Smith, M. L. (1995). Taxonomy of the family Halobacteriaceae and the description of two new genera Halorubrobacterium and Natrialba. J Gen Appl Microbiol 41, 333-350.

Kamekura, M., Dyall-Smith, M. L., Upasani, V., Ventosa, A. \& Kates, M. (1997). Diversity of alkaliphilic halobacteria: proposals for transfer of Natronobacterium vacuolatum, Natronobacterium magadii, and Natronobacterium pharaonis to Halorubrum, Natrialba, and Natronomonas gen. nov., respectively, as Halorubrum vacuolatum comb. nov., Natrialba magadii comb. nov., and Natronomonas pharaonis comb. nov., respectively. Int J Syst Bacteriol 47, 853-857.

McGenity, T. J. \& Grant, W. D. (1995). Transfer of Halobacterium saccharovorum, Halobacterium sodomense, Halobacterium trapanicum NRC 34041 and Halobacterium lacusprofundi to the genus Halorubrum gen. nov., as Halorubrum saccharovorum comb. nov., Halorubrum sodomense comb. nov., Halorubrum trapanicum comb. nov., and Halorubrum lacusprofundi comb. nov. Syst Appl Microbiol 18, 237-243.

McGenity, T. J., Gemmell, R. T. \& Grant, W. D. (1998). Proposal of a new halobacterial genus Natrinema gen. nov., with two species Natrinema pellirubrum nom. nov. and Natrinema pallidum nom. nov. Int J Syst Bacteriol 48, 1187-1196.

Marmur, J. \& Doty, P. (1962). Determination of the base composition of deoxyribonucleic acid from its thermal denaturation temperature. J Mol Biol 5, 109-118.

Montalvo-Rodríguez, R., Vreeland, R. H., Oren, A., Kessel, M., Betancourt, C. \& López-Garriga, J. (1998). Halogeometricum borinquense gen. nov., sp. nov., a novel halophilic archaeon from Puerto Rico. Int J Syst Bacteriol 48, 1305-1312.

Mwatha, W. E. \& Grant, W. D. (1993). Natronobacterium vacuolata sp. nov., a haloalkaliphilic archaeon isolated from Lake Magadi, Kenya. Int J Syst Bacteriol 43, 401-404.

Oren, A., Gurevich, P., Gemmell, R. T. \& Teske, A. (1995). Halobaculum gomorrense gen. nov., sp. nov., a novel extremely halophilic archaeon from the Dead Sea. Int J Syst Bacteriol 45, 747-754.

Oren, A., Ventosa, A. \& Grant, W. D. (1997). Proposed minimal standards for description of new taxa in the order Halobacteriales. Int J Syst Bacteriol 47, 233-238.

Ross, H. N. M. (1982). The extremely halophilic archaebacteria. $\mathrm{PhD}$ thesis, University of Leicester, UK.

Ross, H. N. M. \& Grant, W. D. (1985). Nucleic acid studies on halophilic archaebacteria. J Gen Microbiol 131, 165-173.

Ross, H. N. M., Collins, M. D., Tindall, B. J. \& Grant, W. D. (1981). A rapid procedure for the detection of archaebacterial lipids in halophilic bacteria. J Gen Microbiol 123, 75-80. 
Thompson, J. D., Higgins, D. G. \& Gibson, T. J. (1994). CLUSTAL $\mathrm{W}$ : improving the sensitivity of progressive multiple sequence alignment through sequence weighting, position-specific gap penalties and weight matrix choice. Nucleic Acids Res 22, 4673-4680.

Tindall, B. J. (1992). The family Halobacteriaceae. In The Prokaryotes, 2nd edn, vol. 1, pp. 754-808. Edited by A. Balows, H. G. Trüper, M. Dworkin, W. Harder \& K.-H. Schleifer. New York: Springer.

Tindall, B. J., Mills, A. A. \& Grant, W. D. (1980). An alkalophilic red halophilic bacterium with a low magnesium requirement from a Kenyan soda lake. J Gen Microbiol 116, 257-260.

Tindall, B. J., Ross, H. N. M. \& Grant, W. D. (1984). Natronobacterium gen. nov. and Natronococcus gen. nov., two new genera of haloalkaliphilic archaebacteria. Syst Appl Microbiol $\mathbf{5}, 41-57$.

Torreblanca, M., Rodriguez-Valera, F., Juez, G., Ventosa, A., Kamekura, M. \& Kates, M. (1986). Classification of nonalkaliphilic halobacteria based on numerical taxonomy and polar lipid composition, and description of Haloarcula gen. nov. and Haloferax gen. nov. Syst Appl Microbiol 8, 89-99.

Van de Peer, Y. \& De Wachter, R. (1994). TREECON for Windows: a software package for the construction and drawing of evolutionary trees for the Microsoft Windows environment. Comput Appl Biosci 10, 569-570.
Ventosa, A., Gutiérrez, M. C., Kamekura, M. \& Dyall-Smith, M. L. (1999). Proposal to transfer Halococcus turkmenicus, Halobacterium trapanicum JCM 9743 and strain GSL-11 to Haloterrigena turkmenica gen. nov., comb. nov. Int J Syst Bacteriol 49, 131-136.

Wainø, M., Tindall, B. J. \& Ingvorsen, K. (2000). Halorhabdus utahensis gen. nov., sp. nov., an aerobic, extremely halophilic member of the Archaea from Great Salt Lake, Utah. Int J Syst Evol Microbiol 50, 183-190.

Wang, D. Z. \& Tang, Q. F. (1989). Natronobacterium from soda lakes of China. In Recent Advances in Microbial Ecology-Proceedings of the 5th International Symposium on Microbial Ecology (ISEM 5), pp. 68-72. Edited by T. Hattori, Y. Ishida, Y. Maruyama, R. Y. Morita \& A. Uchida. Japan Scientific Societies Press.

Wang, Z. X., Xu, Y. \& Zhou, P. J. (2000). Taxonomy of a new species of haloalkalophilic archaeon. Acta Microbiol Sin 40, 115-120.

Xu, Y., Zhou, P. \& Tian, X. (1999). Characterization of two novel haloalkaliphilic archaea Natronorubrum bangense gen. nov., sp. nov. and Natronorubrum tibetense gen. nov., sp. nov. Int J Syst Bacteriol 49, 261-266.

Zhou, P. J., Xu, Y., Ma, Y. Q. \& Liu, H. D. (1994). Amplification of 16S rRNA genes from halobacteria by means of PCR technique. Acta Microbiol Sin 34, 6-8 (in Chinese). 